\title{
The Latest Development of Chile-Bolivia Dispute: Questioning International Watercourse Status of Silala/Siloli in ICJ*
}

\author{
Almi Nibach Mauludila** \\ DOI: https://doi.org/10.22304/pjih.v5n3.a2
}

Submitted: September 5, 2018 | Accepted: December 23, 2018

\begin{abstract}
Silala/Siloli is a basin, an international watercourse, flow from highlands of Potosí, Bolivia, to Antofagasta, Chile. Since 1997, Bolivia claims full sovereignty over the watercourse based on the canalisation of Silala/Siloli in 1908. On the other hand, Bolivia has never argued on the existence and status of Silala/Siloli for over 90 years before. Until now, Chile uses the flow to water the cities of Antofagasta, Sierra Gorda, and Baquedano. Recently, the situation is worsened by Bolivia's decision to conduct several projects around Silala/Siloli. Chile filed its objection to the ICJ on June 2016. In 2018, both parties have concluded the written proceeding by submitting their memorials. The oral proceeding for this contentious case is yet to be decided. This study aims to analyze the definition of international watercourse based on international law. The analysis started from the ILC Guiding Principles on Unilateral Declaration capable of creating legal obligations, general principles regarding territorial claim, and relevant bilateral documents between the two States.
\end{abstract}

Keywords: contentious case, ICJ court procedure, international watercourse.

\section{Perkembangan Terakhir Chile v. Bolivia di Mahkamah Internasional: Sengketa Status Silala/Siloli sebagai Jalur Air Internasional}

\begin{abstract}
Abstrak
Silala/Siloli adalah jalur air internasional yang berasal dari dataran tinggi Potosí, Bolivia dan mengalir ke Antofagasta, Chili. Pada tahun 1997, Bolivia mengklaim kedaulatan penuh atas aliran air Silala/Siloli dengan mendasarkan argumen pada kanalisasi di tahun 1908. Di sisi lain, keberadaan dan status Silala/Siloli tidak pernah diperdebatkan oleh Bolivia selama lebih dari 90 tahun. Hingga saat ini, Chili menggunakan Silala/Siloli untuk mengairi kota Antofagasta, Sierra Gorda, dan Baquedano. Baru-baru ini, situasinya diperburuk oleh keputusan Bolivia untuk melakukan beberapa proyek di sekitar Silala/Siloli. Chili mengajukan klaimnya ke ICJ pada Juni 2016 dan pada 2018 kedua belah pihak telah menyelesaikan tahap tertulis dengan mengirimkan memorial. Proses persidangan ini belum ditentukan. Artikel ini akan menganalisis definisi jalur air internasional menurut hukum internasional. Analisis akan dimulai pada Prinsip-Prinsip Panduan ILC tentang Deklarasi Unilateral yang mampu menciptakan kewajiban hukum, prinsip-prinsip umum mengenai klaim teritorial, dan dokumen bilateral yang relevan antara kedua Negara.
\end{abstract}

PADJADJARAN Journal of Law Volume 5 Number 3 Year 2018 [ISSN 2460-1543] [e-ISSN 2442-9325]

This topic is author's undergraduate thesis supervised by Achmad Gusman Siswandi, S.H., LL.M, Ph.D and Davina Oktivana, S.H., M.H.

** Law Graduate of Padjadjaran University, Jl. Dipatiukur No. 35, Bandung, anmauludila@gmail.com, S.H. (Universitas Padjadjaran). 
Kata kunci: jalur air internasional, kasus antar negara, prosedur pengadilan Mahkamah Internasional.

\section{A. Introduction}

Silala/Siloli flows from the highlands of Potosí, Bolivia, into Antofagasta, Chile. ${ }^{1}$ In total, it is 8.5 kilometers in length, ${ }^{2}$ with almost 4 kilometers flow in each States. Silala/Siloli meets San Pedro River and flows into the Pacific Ocean. ${ }^{3}$ The dispute arose since 1997 when Bolivia proposed a claim that Silala/Siloli is not an international watercourse due to the canalization of the watercourse to intensify its waters. They argue that Silala/Siloli flowed artificially into Chilean territory. ${ }^{4}$ Based on this claim, Bolivia claims full sovereignty over Silala/Siloli and compensation from Chile for the use of Silala/Siloli since 1908 until present time. ${ }^{5}$ This dispute further is getting worse and affecting the relation of both States, especially after Bolivia lost its access to the Pacific Ocean in $1883 .{ }^{6}$

The foundation of Bolivian claim is rooted in the concession granted to a railway company named Ferrocarril de Antofagasta a Bolivia (FCAB) in 1906 and 1908 by Chile and Bolivia respectively. Both States granted the concession for its locomotives. ${ }^{7}$ Besides the FCAB, Chile also uses the water of Silala/Siloli for public interests in three cities: Antofagasta, Sierra Gorda, and Baquedano. ${ }^{8}$ Chile still uses the water of Silala/Siloli until present day. In 1997, Bolivia revoked its concession given to FCAB in 1906 to affirm its position on this subject.

Since both states granted the concession until 1997, Bolivia had never questioned the status of Silala/Siloli as an international watercourse. Furthermore, Bolivian Minister of Foreign Affairs issued a written statement in 1996 to affirm the status of Silala/Siloli as an international watercourse.

".... 2. The Silala/Siloli is a river that has its origin in a spring at the foot of the hill of the same name, in Bolivian territory, after which it crosses into Chilean territory. In other words, Bolivia owns the upstream course of this river and Chile owns the downstream course.

1 Christopher P. Rossi, "The Transboundary Dispute Over the Waters of the Silala/Siloli: Legal Vandalism and Goffmanian Metaphor", Stanford Journal of International Law, Vol. 53, No. 1, 2017, p. 56.

2 Ibid.; see International Court of Justice, "Chile Institutes Proceedings Against Bolivia with Regard to a Dispute Concerning the Status and Use of the Waters of the Silala/Siloli", Press Release No. 2016/16, http://www.icjcij.org/docket/files/162/19018.pdf, accessed on October 2017, para. 10 (Application Instituting Proceedings).

3 B.M. Mulligan dan G.E. Eckstein, "The Silala/Siloli Watershed: Dispute over the Most Vulnerable Basin in South America", Water Resources Development, Vol. 27, No. 3, 2011, p. 595.

4 United Nations Environment Program (UNEP), "Hydropolitical Vulnerability and Resilience along International Waters, Latin America and the Caribbeans", UNEP, 2007, p. 64.

5 Application Instituting Proceedings, p. 5, para. 22; Aline Baillat, International Trade in Water Rights, London: IWA Publishing, 2010, p. 91.

6 Laura Lesure, "Tensions Rise between Chile and Bolivia over the Perceived State of the Former's Military Base near the Silala River", Council at Hemisphere Affairs, 2016, p. 2.

7 Fernando Urquidi Barrau, "Water Resources in Bolivia: A Strategic Viewpoint of the Issues Associated with Transboundary Waters", in Blanca Jiménez-Cisneros and José Galizia-Tundisi (eds.), Diagnosis Of Water in the Americas, Mexico: IANAS Water Program, 2013, p. 113; William Rodney Long, Railways of South America: Part 3, Washington: US Government Print Official, 1930.

8 Application Instituting Proceedings, p. 3, para. 11. 
.... 4. The Mixed Bolivia-Chile Commission made an official map that clearly shows that the so-called "dam" or "Silala/Siloli canalization" is on Chilean territory. Therefore there is no water diversion. This was confirmed during the field work that said Mixed Commission carried out in the years 1992, 1993, and 1994"9

The Head of National Sovereignty and Boundary Commission also confirmed the statement made by Bolivian Minister of Foreign Affairs. ${ }^{10}$ This statement was published in La Presencia in May 31, $1996 .^{11}$

"The Silala river is located in the province Sud Lipez of the Department of Potosi and belongs to the jurisdiction that in the beginnings of the century was called the Quetena Vice-Canton. It rises from two main springs and receives additional waters from other minor springs. The narrow river bed that is formed, called Silala, runs approximately two kilometers through Bolivian territory before it crosses the boundary at point of the east-west slop od the glen between the hills Inacaliri and Silala. The inclination of the terrain has been established by experts to be around $30 \%$, its river bed is narrow and its crystalline waters follow the course that, due to the force of gravity, goes downhill into Chilean territory....... On Chilean Territory, it is a tributary of the San Pedro and Loa rivers."

Other evidences of Silala/Siloli as an international watercourse also exists in a map attached to the Treaty of Peace and Friendship 1904 and Antecedentes Limites ChileBolivia. Both Chilean and Bolivian representatives signed the minutes.

After the Bolivian revocation, both states maintain communication through diplomatic notes. They also had established technical commission to handle this subject. $^{12}$ In 2002, however, Bolivia denied the status of Silala/Siloli as an international watercourse and the request for bilateral negotiations with Chile. After two years, Bolivia and Chile finally agreed to establish working group, which unfortunately did not lead to any agreement. The working group was finally replaced by a joint technical work with primary objective to create bilateral agreement on the status and management of Silala/Siloli. Bilateral meetings were held until 2009, when Bolivia reinstated its position on the status and the use of Silala/Siloli, rendering the negotiations between two States futile.

The dispute over the status and use of Silala/Siloli is further worsen when the Governor of Potosí, Bolivia, announced the plans to construct a fish farm, a dam, and a mineral water plant next to Silala/Siloli - projects that would likely effect the water quality and quantity. Based on this announcement, Chile inquired further information to Bolivia regarding the planned projects on May 7, 2012 and October 9, 2012. However, Bolivia did not reply such inquiry and instead reinstated its position

Application Instituting Proceedings, p. 191.

Ibid., p. 5, para. 20-21.

lbid., p. 203.

Ibid., p. 7, para. 27. 
on this matter. Bolivia has indeed constructed a fish pond, a military post, and houses next to Silala/Siloli. ${ }^{13}$

Both Chile and Bolivia are subjects to the America Treaty on Pacific Settlement (Pacta Bogotá) 1948 and the Charter of United Nations. Chile filed the dispute to International Court of Justice (ICJ) on June 6, 2016. They use Article XXXI of Pacta Bogotá, in conformity with Article 36(1) of ICJ Statute, to justify their action.

For contentious cases, the procedure in ICJ consists of written and oral proceedings. The proceedings begin with filing for application to the ICJ. The President then meets the agents of the parties in order to set the number and the order of filing of the written pleadings and the time limits to be filed. ${ }^{14}$ Then, the decision was made into an order. Afterwards, the process would move onto the written proceeding, which involves the submission to the Court of written pleadings containing detailed, adversarial statements of fact and law. ${ }^{15}$ Parties are expected to write memorials and, if requested and deemed necessary, must write Reply and Rejoinder. The oral proceeding will take place a few months after the written proceeding. Both parties will have two rounds of oral argument and the process will take around two or three weeks.

After Chile completed the application on June 6, 2016, the ICJ issued an Order on July 1, 2016 to fix the time limit for each party. Chile was expected to submit their memorial on July 3, 2017 and Bolivia was expected to submit their countermemorial on July 3, 2018. The ICJ later issued another Order on May 23, 2018, which extended the time limit for counter-memorial submission for two months. Now, the dispute has not entered into oral proceeding. Chile requested the ICJ to adjudge and declare the Silala/Siloli an international watercourse and that the utilization of its waters is governed by customary international law.

\section{B. Unilateral Declaration made by State Organs under International Law}

The United Nations General Assembly Resolution 51/160 of 1997 mandates the International Law Commission (ILC) to discuss the topic of the Unilateral Acts of States. In 2006, ILC successfully codified 10 principles called Guiding Principles on Unilateral Declaration to create Legal Obligation (Guiding Principles) that are derived from the decisions of ICJ and Vienna Convention on Law of Treaties 1969 (VCLT 1969). In brief, unilateral declaration means that a state's statement binds it, thus it should be complied. It is very similar to estoppel, since both require states to act consistently and not change their positions. However, according to Jacque, nonperformance of a unilateral declaration does not amount to detrimental reliance of relying State. ${ }^{16}$ Although neither past decisions nor ILC mention 'detrimental

\footnotetext{
Ibid., p. 8, para. 36.

International Court of Justice (ICJ), Handbook of the International Court of Justice, The Hague: The Registrar of the International Court of Justice, p. 51.

15 Ibid., p. 52.

16 Christopher Brown, op.cit., p. 409.
} 
reliance' as a prerequisite, surely non-performance would affect other states. ${ }^{17}$ Other differences pointed out regarding this is the creation of unilateral declaration by an expression of will or the intention of parties. Estoppel, on the other hand, arises from expectation or behavior of the addressee of the act. ${ }^{18}$ Apparently, the differences between both are seen in the requirements and the lack or the existence of detrimental reliance and intention.

\section{Requirements of a Legally Binding Unilateral Declaration}

The ILC codified the requirements for legally binding statement made by a state. Under Principle 1 of Guiding Principles, a declaration that is made publicly and shows a will to be bound will create legal obligation for the declarant. ${ }^{19}$ In conjunction with Principle 1, Principle 3 explains that the content of the statement and factual surrounding circumstances are considered an intention to be bound. ${ }^{20}$ The content of the declaration must be clear and specific. In order to fulfill the 'clear and specific words', the ICJ usually uses restrictive approach to avoid confusion with political statement, ${ }^{21}$ i.e. the use of specific words to obey certain rules. ${ }^{22}$ To avoid confusion, therefore, words such as "move forward to" or "improve their efforts" must be avoided. ${ }^{23}$

An illustration from Armed Activities between Rwanda and Congo might come in handy. The Rwandan Minister of Defense, before the UN General Assembly, stated "...... The few instruments that have not been ratified yet will shortly be ratified and the past reservations that have not been withdrawn yet will shortly be withdrawn." ${ }^{24}$ This statement, according to the ICJ, was unclear or "indeterminate" since it did not specifically refer to which instrument Rwanda would withdraw. ${ }^{25}$ Therefore, the ICJ considered that this statement does not bind Rwanda.

'Factual condition' refers to formal setting where a declaration is made. ${ }^{26}$ For example, Egypt promised before the UN General Assembly to open the Suez Canal for international community after its nationalization in $1956 .{ }^{27}$ However, factual condition could also refer to conditions leading up to the issuance of declaration, such as in Frontier Dispute. The ICJ found that remarks made by Mali regarding its

17 Camille Goodman, "Acta Sunt Servanda? A Regime for Regulating the Unilateral Acts of States at International Law", Australian Year Book of International Law, Vol. 25, No. 43, 2006, http://www.austlii.edu.au/au/journals/AUYrBkIntLaw/2006/3.html\#Heading73, accessed on November 6, 2017. Ibid.

19 Principle 1 of the International Law Commission (ILC) Guiding Principles applicable to unilateral declarations of States capable of creating legal obligations, with commentaries thereto, G.A. Res. A/61/10, September 9, 2006.

20 "To determine the legal effects of such declarations, it is necessary to take account of their content, of all the factual circumstances in which they were made, and of the reactions to which they gave rise."

21 ICJ, Nuclear Tests (Australia v. France), Judgement, ICJ Rep 253, 1974, p. 267, para. 44.

22 Christian Eckart, Promises of States under International Law, Portland: Hart Publishing, 2012, p. 220.

23 Ibid., p. 221.

24 ICJ, Armed Activities on the Territory of the Congo (Democratic Republic of the Congo v. Rwanda), ICJ Rep, 2006, para. 45.

25 Ibid., para. 50.

26 Christian Eckart, op.cit., pp. 224-225.

27 José A Obieta Chalbaud, The International Status of the Suez Canal, $2^{\text {nd }}$ edition, The Hague: Springer, 1970, Chapter I. 
willingness to be bound by mediation body of African Union couldn't be considered as legally binding. This is because Mali had previously refused to be bound by a treaty. ${ }^{28}$

Furthermore, competent state organ plays an important part in establishing a unilateral declaration. Principle 4 states that competent state organ is needed in order to assert whether a declaration really represents a state.

"By virtue of their functions, heads of states, heads of Government, and ministers for foreign affairs are competent to formulate such declarations. Other persons representing state in specified areas may be authorized to bind it, through their declarations, in areas falling within their competence." 29

This principle reflects the judgement of ICJ in Armed Activities where Minister of Defense made the unilateral declaration, about subject that was still within her area of work.

However, assessment must be made in regards to whether or not such organs actually have the powers to represent their states and to bind their states. In treaty law, an organ of state must possess full powers. ${ }^{30}$ In such situations, however, assessment can be made through affirmation. In light of the Nuclear Tests, Alfred P. Rubin posits that the declaration made by French Minister of Defense had been affirmed by its Minister of Foreign Affairs. Hence, without having to determine the existence of full powers, it is concluded that France intended for his statement to be binding. ${ }^{31}$

\section{Types of Legally binding Unilateral Declaration}

Generally, there are four types of unilateral declarations; ${ }^{32}$ promise, recognition, waiver, and protest. ${ }^{33}$ A promise, under international law, means that the declarant manifested its will to be bound through a commitment to do or not to do something. ${ }^{34}$ This gives Addressee State the right to claim fulfillment of such promise. ${ }^{35}$ An example of this kind is nuclear tests where France- through its Minister of Foreign Affairs, Minister of Defense, and written communiqué-stated that France would stop doing its nuclear testing in Pacific Ocean.

"The Office of the President of the Republic takes this opportunity of stating that in view of the stage reached in carrying out the French nuclear defence programme

\footnotetext{
ICJ, Frontier Dispute (Burkina Faso/Mali), Judgment, ICJ Rep 554, 1986, para. 39-40.

International Law Commission (ILC), 'Second Report on Unilateral Acts of States, by Mr. Víctor Rodríguez Cedeño, Special Rapporteur', U.N.Doc.A/CN.4/500/Add.1, 1999, p. 203.

30 Article 7 of Vienna Convention on the Law of Treaties 1969 (VCLT 1969).

31 Alfred P. Rubin, "The International Legal Effects of Unilateral Declaration", American Journal of International Law, Vol. 71, No. 1, 1977, p. 16.

32 Christian Eckart, op.cit., p. 27.

33 Unilateral declaration such as recognition, protest, notification, and waiver have been considered to be customary international law, while promise is a bit harder to classify. See Camille Goodman, op.cit.

34 Antonio Cassese, International Law, Oxford: Oxford University Press, 2005, p. 185.

35 Christian Eckart, op.cit., p. 29.
} 
France will be in a position to pass on to the stage of underground explosions as soon as the series of tests planned for this summer is completed. "36

This statement, which was reassured numerous times by France, indicated the existence of a commitment to not do something. Hence, it is a form of a promise. Other example of this kind is the aforementioned Egypt's promise before the UN General Assembly to open the Suez Canal. ${ }^{37}$ Although this obligation was stipulated already in Constantinople Convention, it still gave reassurance and amounted to a promise. $^{38}$

The most significant kind of unilateral declaration in the current dispute between Chile and Bolivia is recognition. According to Ruda, recognition means that a State acknowledges the existence of certain fact that may be affecting its rights, obligations, or interests. ${ }^{39}$ Through recognition, a state acknowledges a factual condition and the legal implication that follows. ${ }^{40}$ Most famous example is the declaration by Norwegian Minister of Foreign Affairs, acknowledging Denmark's sovereignty over Eastern Greenland. "Today I informed the Danish Minister that the Norwegian Government would not make any difficulties in the settlement of this question." 41

Ten years later, Norway occupied Eastern Greenland and the Permanent Court of International Justice deemed the statement made by Norway binding. Hence, the occupation was held illegal.

From the above illustrations, it is clear that competent state organ and clearand-specific words are very important in determining whether a declaration legally binds. In the Nuclear Tests case, the statement is clear, specific, and not ambiguous, thus it is not confusing. In the Legal Status of Eastern Greenland, it is clear that Ministers of Foreign Affairs represent states. Therefore, the statement made by the Bolivian Minister of Foreign Affairs in 1996 is a recognition of Silala/Siloli's status.

\section{Revocation of Unilateral Declaration}

In the guidelines provided by ILC, revocation cannot be made arbitrarily. Revocation can be made only when there is fundamental change of circumstance, or rebus sic stantibus. This rule is contained in Principle 10 as follows.

"A unilateral declaration that has created legal obligations for the State making the declaration cannot be revoked arbitrarily. In assessing whether a revocation would be arbitrary, consideration should be given to:

\footnotetext{
ICJ, Nuclear Tests (Australia v. France), op.cit., para. 35.

José A Obieta Chalbaud, loc.cit.

Or according to Suy, a pseudo-promise, see: Christian Eckart, op.cit., p. 110.

9 José Maria Ruda, "Recognition of States and Governments" dalam M. Bedjaoui (ed.), International Law: Achievements and Prospects, Paris: UNESCO, 1991, p. 449, para. 3; Camille Goodman, op.cit; Christian Eckart, op.cit., p. 30; ILC, 'Fifth report on unilateral acts of states, by Mr. Victor Rodríguez Cedeño, Special Rapporteur', UN Doc. A/CN.4/525, 2002, p. 99, para. 58; ILC, 'Sixth report on unilateral acts of States, by Mr. Victor Rodríguez Cedeño, Special Rapporteur, UN Doc. A/CN.4/534, 2003, p. 58, para. 25.

40 Christian Eckart, Ibid.

41 Permanent Court of International Justice, Legal Status of Eastern Greenland (Denmark v Norway), Judgment, Series A/B 53, 1933, para. 69-70.
} 
(i) any specific terms of the declaration relating to revocation;

(ii) the extent to which those to whom the obligations are owed have relied on such obligations;

(iii) The extent to which there has been a fundamental change in the circumstances."

The Bolivian government asserted that the statement had been revoked by its sudden change of position, the question remains on the existence of aforementioned conditions.

The rule on fundamental change of circumstances can be found in Article 62 of VCLT 1969. Article 62(1) of VCLT 1969 stipulates that fundamental change of circumstances is a situation "which has occurred with regard to those existing at the time of the conclusion of a treaty, and which was not foreseen by the parties". It can be invoked as a ground to terminate a treaty when the existence of those circumstances constituted an essential basis of the consent of the parties and the effect of the change radically transform the extent of obligations still to be performed under the treaty. The fundamental changes of circumstances, therefore, are they, which cannot be foreseen by parties, constitutes essential foundation of the consent of the parties, and radically transformed the unperformed obligations.

As previously noted, unilateral declaration has legally binding power towards when there is a will to be bound from the declarant that is indicated by the content of the statement ${ }^{42}$ and when the existence of competent state organ. ${ }^{43}$ Unlike in Armed Activities, ${ }^{44}$ the Bolivian Minister of Foreign Affairs has made clear and specific statement through a press release stating that Silala/Siloli is an international watercourse with Bolivia as its upstream state and Chile as the downstream State. ${ }^{45}$ Teodosio Imaña Castro, the Head of Bolivian National Sovereignty, and Boundary Commission, also adopts the same position in his interview with La Presencia on May 31, 1996. ${ }^{46}$ This is similar to the Nuclear Tests ${ }^{47}$ where there are two different state organs stipulating the same statement. Pursuant to the rules set by the ILC and precedents set by the ICJ, there is recognition of Silala/Siloli as an international watercourse, meaning that it exists under the regime of international law.

Based on Article 62 and the statement made by the Bolivian state organ, Bolivia must be able to demonstrate that there is a fundamental change of circumstances. However, international court and tribunals have disregarded any plea asserting fundamental changes of circumstances, thus there is no example on how fundamental change of circumstances is considered under international law. If Bolivia were to assert that the statement made by its State organs should be

Principle 3 of ILC Guiding Principles on Unilateral Declarations Capable of Creating Legal Obligations.

43 ILC, 'Second Report on Unilateral Acts of States, by Mr. Víctor Rodríguez Cedeño, Special Rapporteur', op.cit., p. 203.

44 ICJ, Nuclear Tests (Australia v. France), op.cit., para. 34; ICJ, Nuclear Tests (New Zealand v. France), Judgement, ICJ Rep 457, 1974, para. 44.

45 Application Instituting Proceedings, Annex $N^{\circ} 14$, p. 191.

$46 \quad$ Ibid., Annex N¹5, p. 203.

47 Alfred P. Rubin, op.cit. 
revoked, it can be argued that the most viable ground is not by invoking fundamental change of circumstances.

Other consideration under Article 10 of the ILC Guiding Principles serves best for Chilean position. "The extent to which those to whom the obligations are owed have relied on such obligations" means that reliance shall arises from the delivery of such statement. Chile, for over 90 years, relied on Silala/Siloli waters, which, according to Chile, is an international watercourse. Bolivia, on the other hand, has never refuted the claim. In current dispute, Chile relies on the water of Silala/Siloli for cities of Antofagasta, Baquedano, Sierra Gorda, ${ }^{48}$ and Calama. ${ }^{49}$ As of 2017, total population of Antofagasta is 361.873 citizens; Sierra Gorda's has 10.186 citizens; and Calama has 166.731 citizens. $^{50}$ Furthermore, there are about 112.451 houses in Antofagasta, 570 houses in Sierra Gorda, and 57.307 houses in Calama. ${ }^{51}$ Therefore, the statement made by Bolivia in 1996 only strengthens Chilean claim that Silala/Siloli is an international watercourse, making Chile entitled of the usage over the water.

\section{Acquiescence and Estoppel as Legal Grounds to claim Silala/Siloli as an International Watercourse}

Acquiescence and estoppel are principles of international law ${ }^{52}$ that are generally used in territorial claims dispute. ${ }^{53}$ Acquiescence is an implied consent or tacit agreement towards a certain legal claim. ${ }^{54}$ It takes form in silence of concerned parties and it relies on the surrounding circumstances. ${ }^{55}$ Suy argues that silence can be construed as acceptance, disapproval, or simply does not mean anything, ${ }^{56}$ hence the need to account surrounding circumstances. ${ }^{57}$ According to ICJ, acquiescence happens "when one could have spoken, and should have spoken, silence means consent."58

In the Gulf of Maine involving Canada and USA, period and state organ held an important part to examine acquiescence. The ICJ held that the lack of protest on the use of equidistance principle in mining exploration licenses given by Canadian government from 1964 to 1984 did not amount to acquiescence since the 20-year-

48 Application Instituting Proceeding, para. 11.

49 Ibid., Annex $\mathrm{N}^{\circ} 15$.

50 Institutio Nacional Estadística Antofagasta, "Cantidad de Personas por Sexo y Edad", http://www.censo2017.cl/descargue-aqui-resultados-de-comunas/, accessed on March 2018.

51 Institutio Nacional Estadística Antofagasta, "Cantidad de Viviendas por Tipo", http://www.censo2017.cl/descargue-aqui-resultados-de-comunas/, accessed on March 2018.

52 Ian Brownlie, Principles of Public International Law, $6^{\text {th }}$ edition, Oxford: Clarendon Press, 2003, p. 616.

53 ICJ, Case Concerning Sovereignty over Pedra Branca/Pulau Batu Puteh, Middle Rocks and South Ledge (Malaysia v Singapore), Judgement, ICJ Rep 2, 2008, para. 121; United States Supreme Court, "Georgia v South Carolina, 497 U.S. 376, 1990.

54 Florian Kriener, "Determining and International Watercourse: The Dispute of Chile v. Bolivia concerning the Silala", Revista Tribuna International, Vol. 6, No. 12, 2017, p. 7.

55 Sophia Kopela, "The Legal Value of Silence as State Conduct in the Jurisprudence of International Tribunals", Australian Yearbook of International Law, Vol. 29, No. 87, 2010, p. 90.

56 Ibid.

57 Phil C.W. Chan, "Acquiescence/Estoppel in International Boundaries: Temple of Preah Vihear Revisited”, Chinese Journal of International Law, Vol. 3, No. 2, 2004, p. 429.

$58 \mathrm{ICJ}$, Request for Interpretation of the Judgment of 15 June 1962 in the Case concerning the Temple of Preah Vihear (Cambodia v Thailand), CR2013/3, 2013, p. 74, para. 26. 
span was only "a brief silence" that cannot be considered long enough for an acquiescence claim. Furthermore, state organ who issued the licenses cannot be considered as a competent organ representing Canada. ${ }^{59}$ To elaborate more, the ICJ in Anglo-Norwegian Fisheries held that the lack of protest towards Norway's delimitation system for over 70 years is considered as acquiescence, thus estopping British. From this dispute, it is clear that the requirement for acquiescence is sufficient amount of time.

In both cases, Acquiescence resulted into Estoppel. Estoppel obliges states to act consistently on particular factual situations or legal situations. ${ }^{60}$ Thus, when a state changes its position, it causes detriment to another state who depends on the former's consistent action. In Grisbådarna, the Tribunal held that Norway's failure to protest amounted to acquiescence, resulting to it being estopped from claiming Grisbådarna. ${ }^{61}$

"[t]he stationing of a light-boat, which is necessary to the safety of navigation in the regions of Grisbadama, was done by Sweden without meeting any protest and even at the initiative of Norway, and likewise a large number of beacons were established there without giving rise to any protests; and [t]his light-boat and these beacons are always maintained by Sweden at her own expense. "62

Similarly, in the Minquiers and Ecrehos, lack of protest against British claim towards Minquiers leads to acquiescence. ${ }^{63}$ French tacitly agreed to British claim through its letter.

"By his Note of June 12th, 1820, to the Foreign Office, already referred to above, the French Ambassador in London transmitted a letter from the French Minister of Marine of September 14th, 1819, to the French Foreign Minister, in which the Minquiers were stated to be "possédés par L'Angleterre", and in one of the charts enclosed the Minquiers group was indicated as being British. ....." ${ }^{\prime 64}$

From aforementioned disputes, it can be inferred that acquiescence and estoppel are different aspects of a same institution. ${ }^{65}$

Since silence can amount to acquiescence ${ }^{66}$, which then gives rise to an estoppel, ${ }^{67}$ it is safe to argue that Bolivia has tacitly agreed to Chilean claim that Silala/Siloli is an international watercourse. Especially, Chilean claim is recognized by

59 ICJ, Delimitation of the Maritime Boundary in the Gulf of Maine Area (Canada v United States of America), Judgment, ICJ Rep 246, 1984, pp. 307-308.

60 I.C. MacGibbon, "Estoppel in International Law", International and Comparative Law Quarterly, Vol. 7, No. 3, 1958, p. 468.

61 Nuno Sergio Marques Antunes, Estoppel, Acquiscence and Recognition in Territorial and Boundary Dispute, Durham: University of Durham, 2000, p. 8.

62 Permanent Court of Arbitration, The Grisbådarna (Norway v. Sweden), Award, 1909, p.7.

63 Ian Brownlie, The Rule of Law in International Affairs: International Law at the Fiftieth Anniversary of the United Nations, Netherlands: Kluwer Law International, 1998, p. 158.

64 ICJ, The Minquiers and Ecrehos case (France v. United Kingdom), Judgment, ICJ Reports, 1953, p. 71.

65 Nuno Sergio Marques Antunes, op.cit., p. 24.

66 Florian Kriener, op.cit. p. 7.

67 Jack Wass, "Jurisdiction by Estoppel and Acquiescence in International Courts and Tribunals", the British Yearbook of International Law, Vol. 86, 2017, p. 4. 
Bolivia. It means that Bolivia "could have spoken" ${ }^{68}$ but chose not to. The amount of time also surpasses that of Anglo-Norwegian Fisheries since Bolivia has been silent for over 90 years. It is also important to note that the Bolivian Minister of Foreign Affairs, a competent State organ had reinstated this position. Hence, the legal consequence would mean that Bolivia's silence for 90 years ultimately estopped it from claiming sovereignty over Silala/Siloli.

\section{The Status of Silala/Siloli in Bilateral Documents between Chile and Bolivia}

The existence of maps in international law can be evidence of the existence of a fact, ${ }^{69}$ especially a map attached or appended to the agreement agreed upon by the parties. ${ }^{70}$ In this current dispute, a map annexed in the Treaty of Peace and Friendship 1904 named Silala/Siloli as 'Río Silala'. In addition, Antecedentes Limites Chile-Bolivia -a signed minutes detailing the border marking process- states Silala/Siloli as 'a river' that flows naturally into Chilean territory. However, what significance do these document bear in this dispute?

First, in establishing claims based on the map and signed minutes, the law of treaties should be regarded. A treaty usually provides that an annex or an appendix is an integral part of the treaty ${ }^{71}$ and may dedicate a separate article regulating this. For example, the Law of the Sea Convention Article 318 provides as follows.

"The Annexes form an integral part of this Convention and, unless expressly provided otherwise, a reference to this Convention or to one of its parts includes a reference to the Annexes relating thereto." 72

In this current dispute, the map annexed or appended to the Treaty of Peace and Friendship 1904 was agreed by both parties to be considered as an integral part of the treaty.

"Within the six months following the ratification of this treaty, the High Contracting Parties shall name a commission of engineers to proceed to mark out the boundary line, the points of which, enumerated in this article, are indicated in the appended plan, which shall form an integral part of the present treaty, in conformity with the procedure and in the periods, which shall be agreed upon by special arrangement between the two Foreign Office."73

68 ICJ, Request for Interpretation of the Judgment of 15 June 1962 in the Case concerning the Temple of Preah Vihear (Cambodia $v$ Thailand), loc. cit.

69 Hyung K. Lee, "Applying the Law of Legalizing Maps: the Implications of the Emerging Rule on Map Evidence in International Law", Pacific Rim Law \& Policy Journal, Vol. 14, No. 1, 2005, p. 159; ICJ, Case Concerning Sovereignty over Pedra Branca/Pulau Batu Puteh, Middle Rocks and South Ledge (Malaysia v Singapore), op.cit., para. 271-272.

70 ICJ, Sovereignty over Pulau Ligitan and Pulau Sipadan (Indonesia v Malaysia), Judgment, Merits, ICJ Rep 625, 2002, paras. 72, 85, 91.

71 Anthony Aust, Modern Treaty Law and Practice, $2^{\text {nd }}$ Edition, Cambridge: Cambridge Univeristy Press, 2007, p. 436.

72 Other examples are Article XVII of Chemical Weapons Convention 1933, Article XVII(1) of the IntermediateRange Nuclear Forces Treaty 1987, Article X of Comprehensive Nuclear-Test-Ban Treaty 1996.

73 Article II, Treaty of Peace and Friendship 1904. 
It is clear that the appended map was intended to form an integral part of the present treaty. As High Contracting Parties, both Chile and Bolivia are bound surely by the fact uttered in the map. Furthermore, the appended map served also as the basis for demarcation process documented in Antecedentes Limites Chile-Bolivia. Since both documents state Silala/Siloli as 'Río Silala', this means that Silala/Siloli existed before the canalization, thus the Bolivian claim is invalid.

Then, as long as there is no implication or there is no treaty establishing the status of an annex or an appendix, the appended map can still be considered as an evidence before the ICJ. In fact, the ICJ, on several occasions, considers signed map as an evidence. ${ }^{74}$

\section{E. Silala/Siloli as an International Watercourse under International Law}

1. International Law Association Helsinki Rules $\mathbf{1 9 6 6}$ and Berlin Rules 2004

The International Law Association ("ILA") codifies principles and customary international law related to non-navigational uses of watercourse. ${ }^{75}$ The ILA Helsinki Rules is not a legally binding instrument under international law but it serves as a sign of existing principles and customary international law governing uses of watercourse.

The ILA Helsinki Rules uses the term 'international drainage basin' instead of 'international watercourse'. Article II defines international drainage basin as a 'a geographical area extending over two or more states determined by the watershed limits of the system of waters, including surface and underground waters, flowing into a common terminus' ${ }^{76}$ The ILA further elaborates this definition by clarifying elements of international drainage basin in its commentary of Article II. It is stated that 'an international drainage basin is the entire area, known as the watershed, that contributes water, both surface and underground, to the principal river, stream or lake, or other common terminus.'

Similarly, the ILA Berlin Rules 2004 uses the same definition of international drainage basin. ${ }^{77}$ The ILA Berlin Rules 2004 also contains other definition related to international watercourse, such as 'groundwater'. Though mainly focusing on groundwater, in both instruments ILA has consistently defines 'international' as means a basin that crosses border of two states or more. The ILA, by stating so in both Berlin Rules and Helsinki Rules, agrees that there are no requirements for a water resource to be considered as other than the crossing-states condition.

\section{United Nations Convention on Non-Navigational Uses of International Watercourse 1997}

The United Nations Convention on Non-Navigational Uses of International Watercourses (UN Watercourses Convention) has a broader scope. It includes both

\footnotetext{
74 Hyung K. Lee, Ibid.

75 International Law Association, 'Helsinki Rules on the Uses of the Waters of International Rivers', London: International Law Association, 1967, p. 7.

76 Ibid., p. 8; Commentary of Article II.

77 Berlin Rules 2004, p. 11
} 
surface waters and groundwater. In essence, the UN Watercourses Convention reinstates the principles and customary international law codified by the ILA in Helsinki Rules 1966 with several changes and addition. Neither Chile or Bolivia has ratified the UN Watercourses Convention. However, the UN Watercourses Convention shall serve as an evidence of customary international law and principles under international watercourses law. This convention came into force in 2015 with 36 major states ratifying this convention. ${ }^{78}$

In interpreting the meaning of "international watercourse," this study seeks to rely on Article 31(1) and Article 32 of Vienna Convention on the Law of Treaty 1969 (VCLT 1969). Article 31(1) of VCLT 1969 stipulates that a treaty shall be interpreted in with the ordinary meaning to be given to the terms of the treaty in their context and in the light of its object and purpose. ${ }^{79}$ Pursuant to this rule of interpretation, it is important that the UN Watercourses Convention's definition of 'international watercourse' closely follows the definition of 'international drainage basin'.

"International watercourse" means a watercourse, parts of which are situated in different States." 80

Article 2(a) provides a light to what can be construed as a 'watercourse'. Again, the definition closely follows the ILA Helsinki Rules 1966. "Watercourse" means a system of surface waters and groundwater constituting by virtue of their physical relationship a unitary whole and normally flowing into a common terminus." 81

This definition shall include large watercourses, streams, lakes, and aquifers, although majority of them are located in one state. ${ }^{82}$ The definition shall also apply to rivers, lakes, aquifers, glaciers, reservoirs, and canals. ${ }^{83}$ To provide more light to this matter, Article 32 of the VCLT 1969 states that a recourse must be made to preparatory works of the treaty in the event that there is still ambiguity. ${ }^{84}$ Thus, recourse must be made to the reports of $\mathrm{ILC}^{85}$ previous versions and final version of the UN Watercourses convention.

At the beginning of the UN Watercourses Convention drafting, 'watercourse' includes river, tributary, canal, or lakes, which are situated in territory of two or

78 International Water Law Project, "Status of the Watercourses Convention", https://www.internationalwaterlaw.org/documents/intldocs/watercourse status.html, accessed on February 2018.

79 Article 31 of VCLT 1969.

80 Article 2(b) of United Nations Watercourses Convention 1997 (UNWC).

81 Article 2(a) of UNWC.

82 United Nations Watercourses Convention 1997, "Scope of the Convention \#1", User's Guide Fact Sheet Series, http://www.unwatercoursesconvention.org/documents/UNWC-Fact-Sheet-1-Scope-of-the-Convention-1.pdf, accessed on October 2017.

83 Ibid.

84 Article 32 of VCLT 1969.

85 Judge Sørensen in his dissenting opinion in North Sea Continental Shelf stated that recourse to travaux préparatoires can be found in the debates recorded in ILC Reports, see E. Lauterpacht (ed.), International Law Reports, Vol. 41, Cambridge: Cambridge University Press, 1970, p. 227. 
more states. The Committee concluded this from the questionnaire filled out by states prior to the drafting process. ${ }^{86}$

"The traditional description of an international watercourse as suggested in a number of the replies is any river, canal or lake forming the frontier or traversing the territories of two or more States.... A definition devised for purposes of navigation is not necessarily the best choice for the requirements of the wide range of uses other than navigation." 87

Later in its $32^{\text {nd }}$ Session, the ILC stated that 'watercourse system' is formed from hydrographic components such as rivers, lakes, canals, glaciers, and groundwater forming a single unit. Therefore, the use of a part of system will affect other parts. ${ }^{88}$ Straightforwardly, if a state's use of its watercourse does not affect another state's watercourse in any way, the watercourse cannot be deemed as international watercourse' ${ }^{89}$ It can be concluded that another threshold for an international watercourse is the effect from its uses.

In the case the status of Silala/Siloli, the main concern is whether or not the canalization of Silala/Siloli excludes it from the status of international watercourse. In this regard, the Committee had apparently examined this matter carefully. The main argument against the inclusion of canal into one of the elements of watercourses system is stemmed from its unusual nature. ${ }^{90}$ However, the majority of the ILC members-as supported by Mr. Jens Evensen, the special rapporteur at that time-deemed that canal can be considered watercourses system ${ }^{91}$ and, comprehensively, watercourses system should include rivers, lakes, tributaries, canals, streams and brooks, aquifers, and groundwater. ${ }^{92}$ The definition by Mr. Jens Evensen was further endorsed and adopted in $1991^{93}$ and in 1994. In the 1994 Report, the criteria of a watercourse had become clearer.

1. It must be in unity, meaning that rivers, lakes, aquifers, glaciers, reservoirs, and canals are interconnected. ${ }^{94}$

2. It normally goes to the same end (common terminus). This addition is given considering that different drainage basins artificially connected by canals will

86 ILC, "First report on the law of the non-navigational uses of international watercourses by Mr. Richard D. Kearney, Special Rapporteur”, UN Doc A/CN.4/295, 1976, p. 186, para. 21.

87 lbid.

88 ILC, "Report of the International Law Commission on the work of its thirty-second session" UN Doc A/35/10, 1980, p. 108, para. 90.

89 Ibid.

90 Tamar Meshel, "What's in a name? Silala Waters and the applicability of international watercourse law", Questions of International Law, Vol. 12, No. 39, 2017, p. 12.

91 ILC, "Report of the International Law Commission on the work of its thirty-ninth session" UN Doc A/42/10, 1987, p. 143 , para. 6 .

92 ILC, "First report on the law of the non-navigational uses of international watercourses, by Mr Jens Evensen, Special Rapporteur", UN Doc A/CN.4/367, 1983, p. 159, para. 20 and p. 168, para. 72.

93 ILC, "Seventh report on the law of the non-navigational uses of international watercourses, by Mr Stephen C McCaffrey, Special Rapporteur", UN Doc AICN.4/436, 1991, p. 51, para. 15 and p. 58, para. 50.

94 ILC, "Report of the International Law Commission on the work of its forty-sixth session: chapter III (The law of the non-navigational uses of international watercourses)" UN Doc A/CN.4/L.500, 1994, p. 90, para. 4. 
unnaturally unite different watercourses system. The result is not desired by the members of the ILC. ${ }^{95}$

There are two conclusions that can be taken from the ILC Report. First, the definition of an international watercourse used by the ILC is simple: a water resource that crosses two or more states and flows into common terminus. Second, the Drafting Committee of the UN Watercourse Convention considers canal as a part of watercourse systems as long as it does not artificially connect different drainage basins. For instance, is the acknowledgement of artificial canal at Cunovo as a part of Danube by the ICJ in Gabcikovo-Nagymaros. ${ }^{96}$

In addition, Brownlie argues and supports the idea that the criteria for an international watercourse, or international rivers, is a water resource that crosses two or more State.

"The term 'international' with reference to rivers is merely a general indication of rivers which geographically and economically affect the territory and interests of two or more states."

By interpreting Article 2(a) and Article 2(b) of the UN Watercourses Convention in this light, it is clear that a canal is considered as a part of watercourses system ${ }^{98}$ as long as it does not artificially connect and unite different drainage basins. ${ }^{99}$ The lack of other requirements means that any watercourse that crosses two or more states automatically becomes 'international'. Following this line of thought, the Silala/Siloli has fulfilled the requirement to be an international watercourse since it naturally crosses into Chilean territory. The canalization made by the FCAB does not unite two different drainage basins-it merely enhances the volume of Silala/Siloli.

\section{F. Conclusion}

The question of Silala/Siloli's status can be answered with three foundations. The first can be derived from unilateral declaration made by competent state's organ. Based on international law, the statement must have a clear and specific wording to determine the intention of the declarant. The statement usually avoids the use of such words like "move forward to" or "improve their efforts" to make it as clear as possible. Factual condition must also be taken into account. Since Bolivia, by its Minister of Foreign Affairs, issued a statement, a unilateral declaration may serve as a foundation to establish the international status of Silala/Siloli.

The second basis in ascertaining the status is through acquiescence and estoppel. As illustrated in previous disputes, such as Anglo-Norwegian Fisheries Case and Grisbådarna, acquiescence may give rise to estoppel, meaning that acquiescence and estoppel are different aspects of the same institution. Furthermore, sufficient amount of time as illustrated in the Gulf of Maine and Anglo-

\footnotetext{
ILC, "Summary record of the 2228th meeting", UN Doc A/CN.4/SR.2228, 1991, p. 141, para. 70.

ICJ, Gabčikovo-Nagymaros Project (Hungary v Slovakia), Judgment, Merits, ICJ Rep 7, 1997, para. 78.

Ian Brownlie, Principles of Public International Law, op.cit., p. 267.

98 ILC, "First report on the law of the non-navigational uses of international watercourses, by Mr Jens Evensen, Special Rapporteur", op.cit.

99 ILC, "Summary record of the 2228th meeting", op.cit.; Ian Brownlie, Ibid.
} 
Norwegian Fisheries Case is needed to establish acquiescence and estoppel. Silence of Bolivia for over 90 years is proven to be sufficient enough for acquiescence and estoppel under the standard used in the Anglo-Norwegian Fisheries Case. Hence, status of Silala/Siloli as an international watercourse can be based on acquiescence and estoppel.

The third can be found in the interpretation of 'international watercourse'. According to the UN Watercourses Convention, the fact that Silala/Siloli is an artificial canal does not undermine its status as an international watercourse. Following the rule of interpretation stated under Article 31(1) of VCLT 1969, the UN Watercourses Convention, the ILA Helsinki Rules 1966, and the Berlin Rules 2004 agree that 'international' element only refers to its existence in two or more States. Based on the preparatory work of the UN Watercourses Convention, it is clear that the international law also endorses the idea that a canal is considered an international watercourse with the condition that it does not artificially unite different watercourses systems. Furthermore, the map appended to the Treaty of Peace and Friendship in 1904 and the Antecedentes Limites Chile-Bolivia iterate that Silala/Siloli has existed naturally prior to the canalization.

Overall, the current evidences show that Chile may have better position in this dispute. Pursuant to the procedure of ICJ, it leaves everything to the oral proceedings to reveal whether or not Silala/Siloli is an international watercourse. If the ICJ decide that Silala/Siloli is an international watercourse, both Bolivia and Chile will have to obey the international law. On a final note, the decision of the ICJ over the status of Silala/Siloli will be a landmark and a development of international watercourses law.

\section{References}

\section{Books}

Antunes, Nuno Sergio Marques, Estoppel, Acquiescence and Recognition in Territorial and Boundary Dispute, University of Durham, Durham, 2000.

Aust, Anthony, Modern Treaty Law and Practice, $2^{\text {nd }}$ edition, Cambridge University Press, Cambridge, 2007.

Baillat, Aline, International Trade in Water Rights, IWA Publishing, London, 2010.

Brownlie, lan, Principles of Public International Law, $6^{\text {th }}$ edition, Clarendon Press, Oxford, 2003.

Brownlie, Ian, The Rule of Law in International Affairs: International Law at the Fiftieth Anniversary of the United Nations, Kluwer Law International, Netherlands, 1998.

Cassese, Antonio, International Law, Oxford University Press, Oxford, 2005.

Chalbaud, José A Obieta, The International Status of the Suez Canal, $2^{\text {nd }}$ ed., Springer, the Hague, 1970.

Eckart, Christian, Promises of States under International Law, Hart Publishing, Portland, 2012.

Jiménez-Cisneros, Blanca dan José Galizia-Tundisi (eds.), Diagnosis of Water in the Americas, IANAS Water Program, Mexico, 2013. 
Lauterpacht, E. (ed.), International Law Reports, Vol. 41, Cambridge University Press, Cambridge, 1970.

Ruda, José Maria, 'Recognition of States and Governments' in M. Bedjaoui (ed.), International Law: Achievements and Prospects, UNESCO, Paris, 1991.

Spilki, Fernando Rosado, (et.al.), Enhancing Water Management Capacity in a Changing World: The Challenge of Increasing Global Access to Water and Sanitation, Universidade Feevale, Novo Hamburgo, 2016.

UNEP, Hydropolitical Vulnerability and Resilience along International Waters, Latin America and the Caribbeans, UNEP, 2007.

William Rodney Long, Railways of South America, Part 3, US Government Print Official, Washington, 1930.

\section{Other Documents}

Chan, Phil C.W., "Acquiescence/Estoppel in International Boundaries: Temple of Preah Vihear Revisited", Chinese Journal of International Law, Vol. 3, No.2, 2004. Goodman, Camille, "Acta Sunt Servanda? A Regime for Regulating the Unilateral Acts of States at International Law" Australian Year Book of International Law, Vol. 25, No. 43, 2006, http://www.austlii.edu.au/au/journals/AUYrBkIntLaw/2006/3.html\#Heading73, accessed on November 2017.

lesure, Laura, "Tensions Rise between Chile and Bolivia over the Perceived State of the Former's Military Base near the Silala River", Council at Hemisphere Affairs, 2016.

Institutio Nacional Estadística Antofagasta, "Cantidad de Personas por Sexo y Edad", http://www.censo2017.cl/descargue-aqui-resultados-de-comunas/, accessed on March 2018.

Institutio Nacional Estadística Antofagasta, "Cantidad de Viviendas por Tipo", http://www.censo2017.cl/descargue-aqui-resultados-de-comunas/, accessed on March 2018.

International Court of Justice, "Chile Institutes Proceedings Against Bolivia with Regard to a Dispute Concerning the Status and Use of the Waters of the Silala/Siloli, Press Release No. 2016/16 (June 6, 2016)", http://www.icjcij.org/docket/files/162/19018.pdf, accessed on October 2017.

International Water Law Project, "Status of the Watercourses Convention", https://www.internationalwaterlaw.org/documents/intldocs/watercourse statu s.htmlaccessed on February 2018.

Kopela, Sophia, "The Legal Value of Silence as State Conduct in the Jurisprudence of International Tribunals", Australian Yearbook of International Law, Vol. 29, Australian National University School of Law, Canberra, 2010.

Kriener, Florian, "Determining and International Watercourse: The Dispute of Chile v. Bolivia concerning the Silala", Revista Tribuna International, Vol. 6, No. 12, 2017. 
Lee, Hyung K., "Applying the Law of Legalizing Maps: The Implications of the Emerging Rule on Map Evidence in International Law", Pacific Rim Law \& Policy Journal, Vol. 14, No. 1, 2005.

MacGibbon, I.C., "Estoppel in International Law", International and Comparative Law Quarterly, Vol. 7, No. 3, 1958.

Meshel, Tamar, "What's in a name? Silala Waters and the applicability of international watercourse law", Questions of International Law, Vol. 12, No. 39, 2017.

Mulligan, B.M. dan G.E. Eckstein, "The Silala/Siloli Watershed: Dispute over the Most Vulnerable Basin in South America", Water Resources Development, Vol. 27, No. 3, 2011.

Rossi, Christopher P., "The Transboundary Dispute Over the Waters of the Silala/Siloli: Legal Vandalism and Goffmanian Metaphor", Stanford Journal of International Law, Vol. 53, No. 1, 2017.

Rubin, Alfred P., "The International Legal Effects of Unilateral Declaration", American Journal of International Law, Vol. 71, No. 1, 1977.

United Nations Watercourses Convention 1997, "Scope of the Convention \#1", User's Guide Fact Sheet http://www.unwatercoursesconvention.org/documents/UNWC-Fact-Sheet-1-

Scope-of-the-Convention-1.pdf, accessed on October 2017.

Wass, Jack, "Jurisdiction by Estoppel and Acquiescence in International Courts and Tribunals", the British Yearbook of International Law, Vol. 86, Oxford University Press, Oxford, 2017.

\section{Legal Documents}

Treaty of Peace and Friendship 1904.

Chemical Weapons Convention 1933.

Vienna Convention on the Law of Treaties 1969.

Intermediate-Range Nuclear Forces Treaty 1987.

Comprehensive Nuclear-Test-Ban Treaty 1996.

United Nations Watercourses Convention 1997.

International Law Commission Guiding Principles on Unilateral Declarations Capable of Creating Legal Obligations.

International Court of Justice, The Minquiers and Ecrehos case (France v. United Kingdom), Judgment, ICJ Reports, 1953.

253, 1974.

-, Nuclear Tests (Australia v. France), Judgement, ICJ Rep Delimitation of the Maritime Boundary in the Gulf of Maine Area (Canada v United States of America), Judgment, ICJ Rep 246, 1984.

Rep 554, 1986. -, Frontier Dispute (Burkina Faso/Mali), Judgment, ICJ Gabčikovo-Nagymaros Project (Hungary v Slovakia), Judgment, Merits, ICJ Rep 7, 1997. 
Armed Activities on the Territory of the Congo

(Democratic Republic of the Congo v. Rwanda), ICJ Rep, 2006.

, Case Concerning Sovereignty over Pedra Branca/Pulau

Batu Puteh, Middle Rocks and South Ledge (Malaysia v Singapore), Judgement,

ICJ Rep 2, 2008.

International Law Commission, Request for Interpretation of the Judgment of 15 June

1962 in the Case concerning the Temple of Preah Vihear (Cambodia v Thailand), CR2013/3, 2013.

-, "First report on the law of the non-navigational uses

of international watercourses by Mr. Richard D. Kearney, Special Rapporteur", UN Doc A/CN.4/295, 1976.

-, "Report of the International Law Commission on the work of its thirty-second session" UN Doc A/35/10, 1980.

-, "First report on the law of the non-navigational uses of international watercourses, by Mr Jens Evensen, Special Rapporteur", UN Doc A/CN.4/367, 1983.

work of its thirty-ninth session" UN Doc A/42/10, 1987.

-, "Seventh report on the law of the non-navigational

uses of international watercourses, by Mr Stephen C McCaffrey, Special Rapporteur", UN Doc AICN.4/436, 1991.

A/CN.4/SR.2228, 1991.

-, "Summary record of the 2228th meeting", UN Doc

, "Report of the International Law Commission on the

work of its forty-sixth session: chapter III (The law of the non-navigational uses of international watercourses)" UN Doc A/CN.4/L.500, 1994.

, 'Second Report on Unilateral Acts of States, by Mr.

Víctor Rodríguez Cedeño, Special Rapporteur', U.N.Doc.A/CN.4/500/Add.1, 1999.

'Fifth report on unilateral acts of states, by Mr. Victor

Rodríguez Cedeño, Special Rapporteur', UN Doc. A/CN.4/525, 2002.

-, 'Sixth report on unilateral acts of States, by Mr.

Victor Rodríguez Cedeño, Special Rapporteur, UN Doc. A/CN.4/534, 2003.

Permanent Court of International Justice, Legal Status of Eastern Greenland

(Denmark v Norway), Judgment, Series A/B 53, 1933.

United States Supreme Court, Georgia v South Carolina, 497 U.S. 376, 1990. 